\title{
THE OPPORTUNITIES AND CHALLENGES OF MAKASSAR GOVERNMENT TOWARDS IMPROVING SERVICES FOR PUBLIC COMPLAINTS BASED ON E-GOVERNMENT
}

\author{
Alim Bubu Swarga, Riska Sarofah, and Siti Hidayatul Juma'ah \\ Universitas Muhammadiyah Yogyakarta \\ Jl. Lingkar Selatan, Kasihan, Bantul, Yogyakarta, Indonesia 55183 \\ E-mail: alimbubuswarga@gmail.com
}

\begin{abstract}
The development of e-Government in Indonesia is increasingly growing in an attempt to give the public services based on ICT (Information and Communication Technologies). E-Government policy is in accordance with the Instructions of the President of Republic Indonesia number 3 in 2003 about policy and national strategy for the development of e-Government in an effort to facilitate the interests and demands of the society. The development of e-Government needs to be planned and implemented through measureable goals for public service in Indonesia. e-Government is one of the principal dimensions of the system of state administration. The implementation of the concept of information technology by the government to make the state administration system to be more effective, efficient, and transparent. One of the city in Indonesia which try to implement e-Government in improving public service is Makassar. This study aims to examine the opportunities and challenges of Makassar government towards improving services for public complaints based on e-Government. One of the strategy and innovation is undertaken by the Makassar government by way of creating e-aspiration. To examine the opportunities and challenges of Makassar Government to improve services for public complaints which based e-Government, we conducted literature study on relevant with previous research and statistical data. Makassar government has shown its enthusiasm surrounding the use of information and technology in many occasions. However, the use of e-aspiration by the government and society are still limited. Therefore, despite that e-aspiration may bring greater benefit in improving good governance. However, this issue of e-aspiration remains difficult in Makassar and in general for Indonesia due to many challenges and obstacles on several dimensions. In consideration of the opportunities and challenges of e-Government is also to be seen from the aspect of society participation in the use of technology and responsiveness of the Government in the development of e-Government services.
\end{abstract}

Keywords: e-government, public complaints, makassar city, government's opportunities and challenges

\section{INTRODUCTION}

Globalization is a phenomenon that expects efficient and effective creation in various countries in the world today.
The advancement of technology, communication, and transportation has made the mobility of people, objects, and information that it can be done quickly, precisely and accurately. Thereupon, it 
isable to reach the region widely and without limitation (KOMINFO, 2015).

The progress of information, communication, and technology has changed the implementation of all sector activities as an example of industry sector, trade, government development. The active involvement in the information, communication and technology revolution will determine the future. The use of information, communication and technology or ICT has grown widely, which is not limited to industry and trade, but also other areas such as defense, security, education, social, labor and so on(William J. Kramer, 2007).

The use of ICT is very advantageous when compared with manual system and traditional way. So many countries and almost all countries in the world have used information, communication, and technology in implementing various systems in their country, especially those related to the governance system.

The government has an obligation to provide equitable public service to all citizens, so that in the framework of carrying out its obligations. The government tries to improve its services using information technology in accordance with the needs of organizations that are able to compile data quickly, effectively and efficiently as well as produce the right information. In these needs the government develops electronic-based services (e-Government).

According to the United Nations, e-Government is the Use of Information Communication Technology and its application by the government to provide public information and services to the public. The goal of e-Government is to provide efficient government information management to all citizens, better service to the community, and empower communities through access to information and participation in public decision making (European Parliamentary Research Service, 2015).

In addition, the World Bank's definition is also relatively broad, i.e. "e-Government refers to the use of information technology by government agencies (e.g. wide area networks, internet, and mobile computing) that have the ability to transform relationships with communities, businesses and stakeholders and other from the government(Maja Bott, 2014). Thereupon, the areas of e-Government have been divided into 3 general functions which can be seen in the figure 1 .

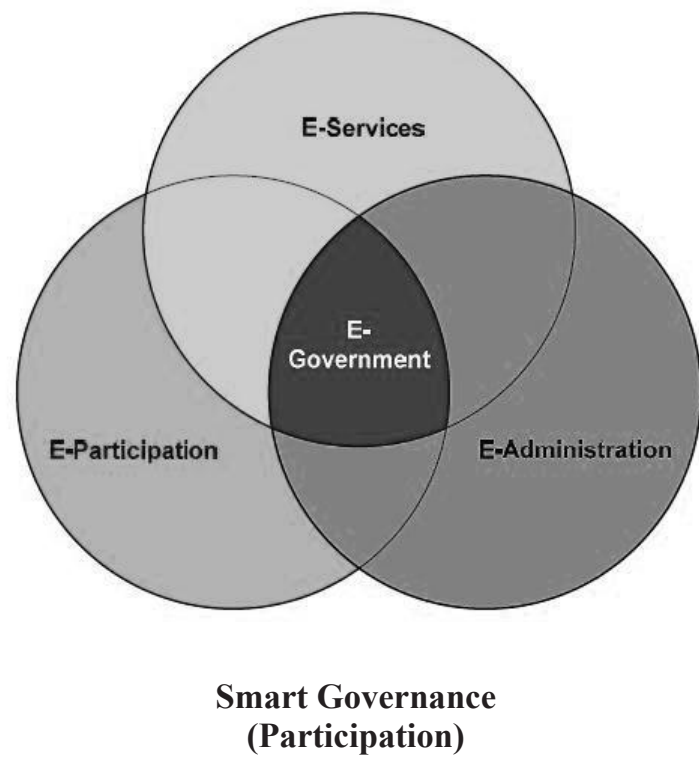

Figure 1

The Areas of e-Government

Source: The Indian Journal of Political Science (2003)

In Indonesia, e-Government was officially introduced to public administration by Presidential Instruction No 6/2001 on Telematics, which states that the government of Indonesia has to 
use telematics technology to support good governance. Furthermore, e-Government should have been introduced for different purposes in government offices.

In Indonesia, e-Government is needed for the following reasons(Tisyo Haryono, 2016):

1. To maintenance the government change towards a democratic governance practices;

2. To encouragement the application of authority balances between central and local government;

3. To simplify communication between central and local governments;

4. To expansion openness; and transformation towards information society era.

In addition, the implementation of e-Government in Indonesia based on the desire to provide convenience to the public in obtaining information as a form of best service to the community. The government has issued Presidential Instruction No.
3/2003 on National Policy and Strategy of e-Government development where the policy is the legal umbrella of all technical detail policy in the field of e-Government. The development of e-Government is an effort to develop electronic government based (using) in order to improve the quality of public services effectively and efficiently. The Indonesian government itself has made roadmap in the implementation of e-Government in Indonesia which can be seen in the figure 2 (KOMINFO, 2012).

Through e-Government, the development of management system arrangement and work process in the government environment by optimizing the utilization of information technology can be done. Utilization of information technology includes 2 (two) related activities are: (Instruksi Presiden, 2003):

1. Data processing, information management, management systems and work processes electronically;

\section{Indonesia's Roadmap to e-Government}

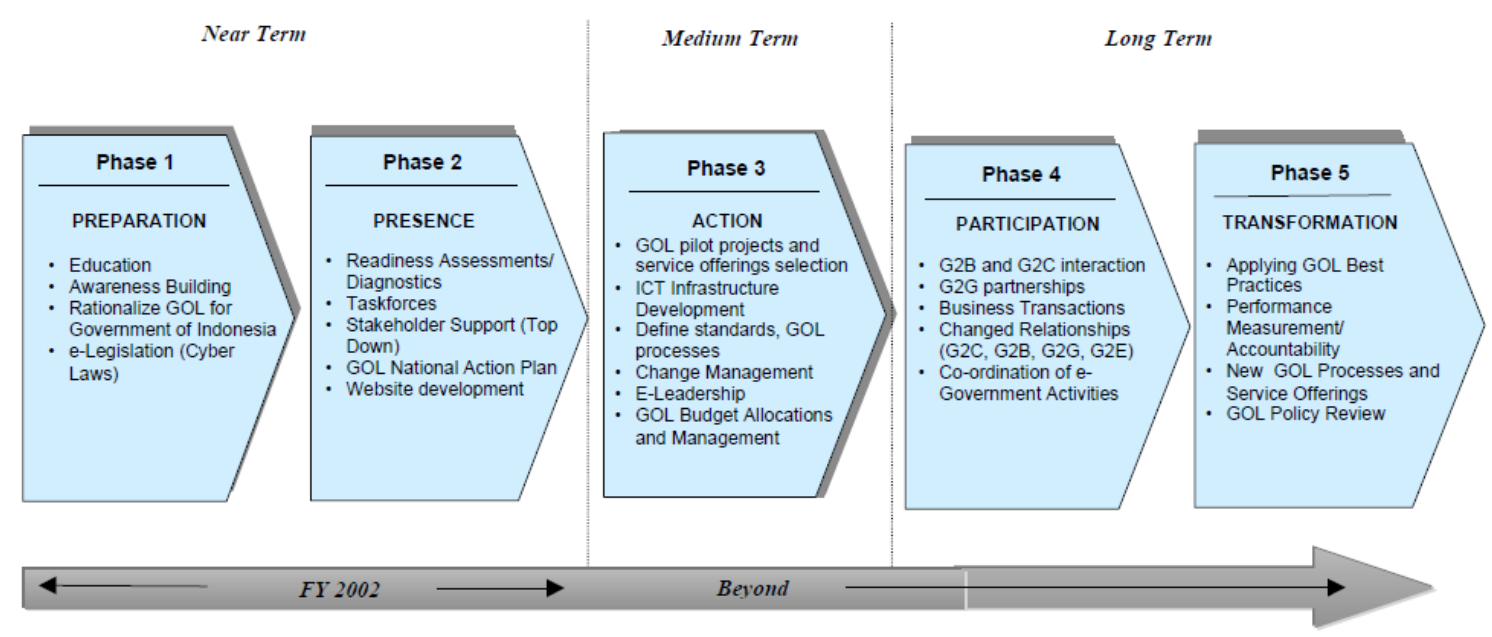

Figure 2

Indonesia's Roadmap to e-Government

Source: Ministry of Communication and Informatics of Indonesia (2012) 
2. Utilization of advances in information technology, so as to public services can be accessed easily and cheaply by people in all regions of the country.

In addition, Presidential Instruction No. 3/2003 describes six strategies of e-Government development that is(Tisyo Haryono, 2016):

1. How to develop a reliable and reliable service system, and affordable to the wider community;

2. How to organize the management system and work process of government and local government autonomously holistically;

3. How to Utilize information technology optimally;

4. How to increase the role of business world and develop telecommunication industry and information technology;

5. How to develop human resource capacity both for government and autonomous regional governments, together with improving community e-literacy; and

6. How to conduct systematic development through realistic and measurable stages.

Thereupon, changes are expected to build clean and transparent government which is capable to respond the changes effectively, to build a new dimension into organization, management system and process, public service, and soon applying the transformation process towards e-Government.

In this case, Makassar city also participates in e-Government services. As one of the most consistent cities in Indonesia to implement smart city. Makassar City seeks to maximize public services by using E-Government as an example by providing complaints of services either through the internet or through other government electronic devices (SMS, telephone) which can be divided into several levels, namely the provision of complaints, information provision, one-way interaction, Twoway and transaction which means full electronic service. One-way interaction can be a facility to download the required information (Ecquria, 2016).

Handling complaints online is an example of a two-way interaction. While full electronic services in the form of decision making and delivery (payment). Based on the fact that the implementation of e-Government in Indonesia most of the time at the publication stage of the site by the government or new at the stage of providing information. But it should be underlined that e-Government is not just a publication site by the government. Providing services up to the full-electronic delivery service stage should be pursued (Fajri Siregar, 2017).

However, the management of e-Government based public service complaints in Makassar city of South Sulawesi province faces some of the challenges especially faced by government organizations. One of them is the problem of inadequate human resources.

Implementation of e-Government in public offices should be supported by employees who understand the technology. And also needed are employees who want to learn and able to respond to changes (manage change). Information technology is changing rapidly so that the willingness of learning is required to have every employee of public institutions. In addition, the management of public service complaints based on e-Government 
requires changes in the organization and support new skills(Ecquria, 2016). Therefore, this papers aims to see how the implementation e-Aspiration and public complaint in Makassar and what are the challenges it may encounter.

\section{MATERIAL AND METHODS}

\section{E-Government Service}

The

World

Bank (2011) e-government is the use of the information and technology by government institutions to improving relations citizens, businesses, and with fellow Government itself. Information and technology provides many benefits in the field of government service improvement, increasing intraction with business and industry, as well as the empowerment of citizents through the management of Government information or making effective and efficient. It has benefits to reduce corruption, increase transparency, greater convenience, revenue growth, and cost reduction (Cordella and Tempini N, 2015).

E-goverment is an electronic service can be affects to the life of the community with interaction with the Government. The Trust became one of the strong construction that greatly influences the use of technology (Abu-Shanab, 2014) (Weerakkody, 2016). E-government is a tool in providing information and services electronically to citizents rather than through traditional channels. E-government can be classified into three main categories; these are (Al-Naimat et al, 2012 as cited by Abu Shanab, 2014):

1. The Government to the citizen (G2C)

2. The Government and business (G2B)

3. The Government and their employees (G2E)

In other hand, Donald f. Norris and Christopher g. Reddick also describe that e-government is the adoption of an extension that is innovative in providing information and Government services to the citizens (G2T), business (G2B) and Government (G2G). The public can receive a lot of information faster and more efficient and able to interact with Government or other sectors that are not limited by time and distance compared to previous (f. Norris, Donald, 2012). 4 dimensions of e-government services these are:

1. The provision of digital service on citizents and businesses.

2. Improve of public service.

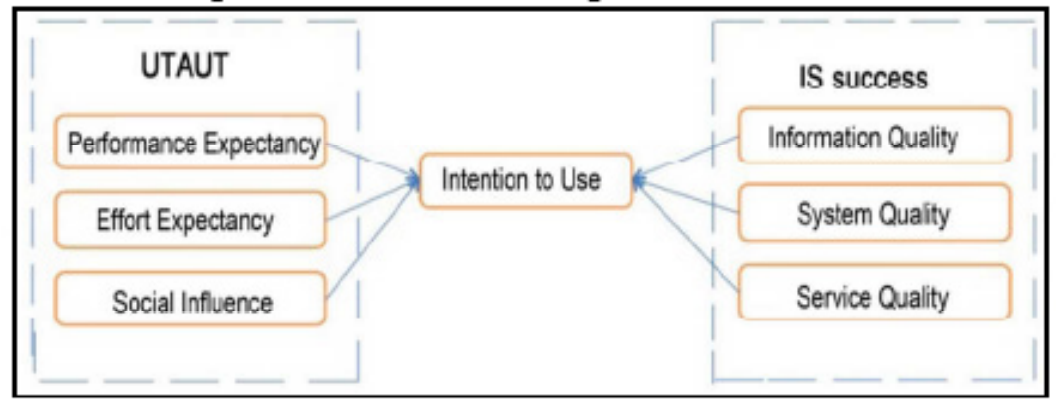

Figure 3

The UTAUT Model of E-government Service

Source: Long Lu and Van Trung Nguyen, 2016: 1501 
3. Facilitate democratic process.

4. Maintain the necessary social development and bridging the digital divide.

To see the willingness of people to use e-government can be seen by using UTAUT model which can be seen in the figure 3 .

E-government services of citizen participation in adopting e-Government are influenced by specific factors. Those factors need to know can be input for the Government in increasing the participation of the community to adopt or make use of e-government services, so that e-government provided the Government does not become useless. Because of that, then the assessment of factors that affect the acceptability and use of e-Government is the important thing.

That's factors can be affect the acceptability and use of e-government measured using a model of Unified Theory of Acceptance and Use Technology (UTAUT). Validation of UTAUT model is the empirical basis that has four main variables that influence behavioral intention and use behavior, the variable is performance expectancy, effort expectancy, and social influence.
Acceptance of public to use e-government services is also influenced by the information quality (quality information), the quality of service (quality information and the quality of system (system quality) (Long Lu and Van Trung, 2016).

\section{Smart City}

The implementation of smart city can not be an integral part of e-government. Implementasion of smart city in Makassar should already be ensured by implements the concept of e-government. However, the related special smart city that includes seven dimensions are: smart eco, smart people, smart governance, smart mobility, smart environment and smart living.

Smart city is an Urban area that creates sustainable economic development and a high quality of life for the citizens by increasing 6 subjects matter (government, economic, quality of life, environment, human resources, and transport) can be done with the quality information and technology (Yang, 2012). The dimensions of smart city on the web-based public complaints included into the category of smart governance.

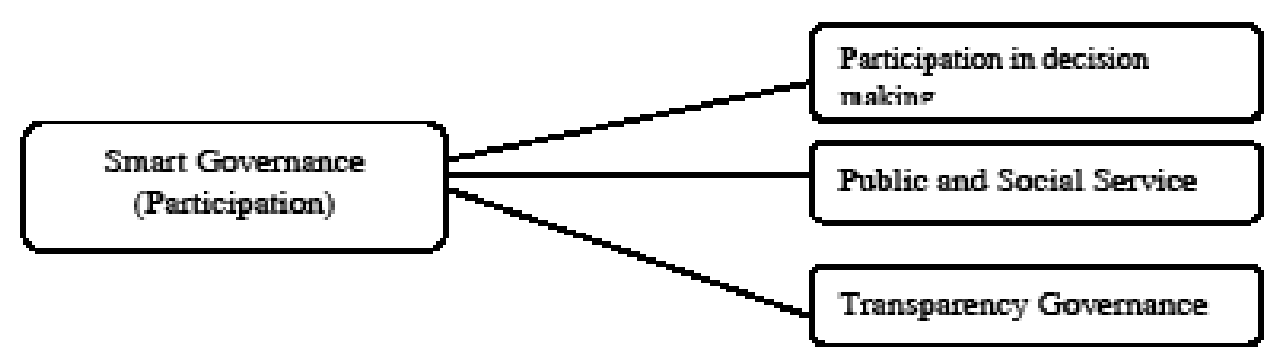

Figure 4

Concept of Smart Governance

Source: Griffinger, et al 2007 in PSPPR UGM 2016 
The government provides the means for the public to give ideas, suggestions, criticism, and desires direcly. Online system via smart phone rated highly effective. In a short time, the government gave the right solutions and responses related to claims submitted (J Hius, 2016). Smart city concept also allows the urban communities can participate in governance and urban management by being an avtive community (Monfaredzadeh and Kruegur, 2015). The concept of smart city can included 3 aspect which we can seen in figure 4.

\section{Public Complaints Service}

The principle of public complaints to the Government attempted in order to facilitate the public who will convey its complaint, among other things by providing services, facsimile hotline and web site as a means of facilitating public complaints. General purpose complaint handling in providing the systems, procedures, and mechanisms that allow any complaints or protests from all sides can be managed well so as not to cause turmoil and disrupting the smooth running of activites of e-government instituion.

Complaints are managed properly will have a substantial benefit or advantage for the organization complaints, among athers (BAPPENAS, 2010):

1. Organizations are increasingly aware of shortcomings or weaknesses in providing service to the costumer.

2. As a means of intropection for the organization are always responsive and willing to pay attention to the "voice" and "preferred" costumers.

3. Make it easy to find a way out of the organization increased quality of his institutions/organization.
4. The customer feels immediately addressed, so their complaints are cleared.

5. Can thicken the flavor - trust and customer loyalty for the Organization.

6. Handling of complaints that could actually improve costumer satisfaction.

The elements in the handling of complaints, among others (BAPPENAS, 2010):

1. The source of the complaint

The source of the complaint is a community, both individually or group, from which the complaint or the complaint originated. Ough to be emphasized here that the complaints is not limited.

2. The contents of the complaint

The contents of the complaint are that defendants by the complainant. The complaint can concern a wide variety of things, ranging from errors of procedure, eror management, staff attitude, quality of service, etc.

3. Unit of complaints handling

Unit of complaints handling is a unit that is provided by each institution to manage and handle matter where complaints are coming from and through any channel.

4. Complaint responds

Complaint response in generated by the unit responds the handling of complaints in their respective government institutions related to the complaint. This responds then communicated to the parties the complainant. Public complaints are an important element in regional agencies, because the complaint was aimed at fixing a lack of activites that have been conducted (Prasetya, at al, 2016). 
5. Feedback

Feedback is the assessment of the parti es the complainant over respond or answer each institution regarding the problem their pose.

6. Report on the handling of complaints

Report of the handling complaint after feedback from a choice of filing a complaints management unit is obligated to make a report about the complaint and its handling of the complaint, including feedback from ligigants.

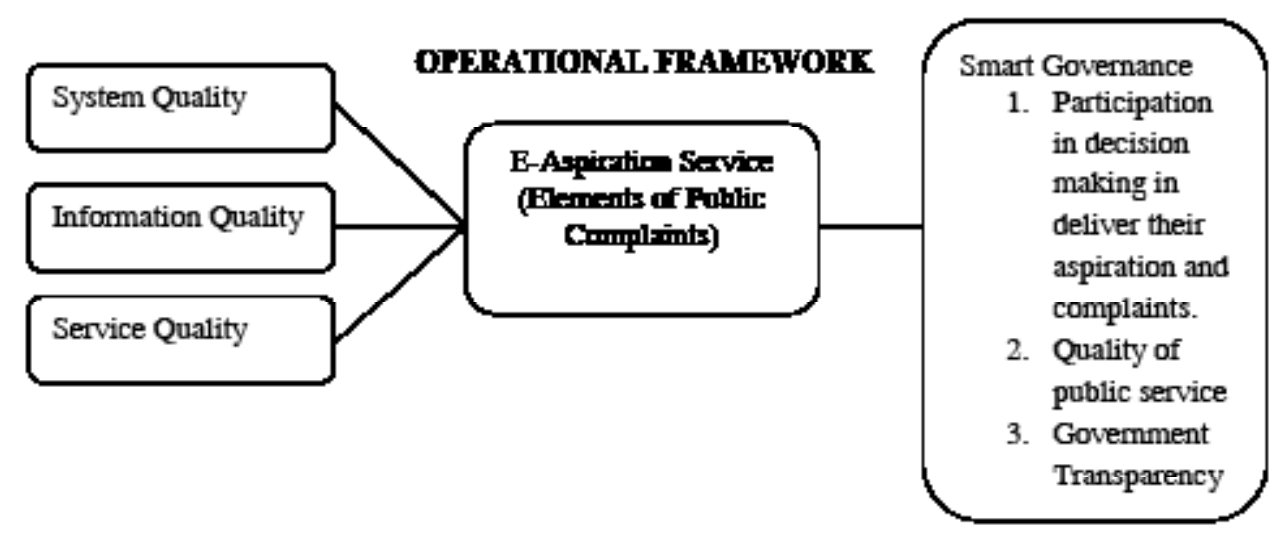

\section{RESEARCH METHODS}

This research is library research with data collection was conducted through literature review by collecting various journal articles, websites, reports and books.

The collected data were then described and analyzed to satisfy the research purposes.

\section{RESULT AND DISCUSSION}

\section{Smart City Implementation in Makassar City}

The implementation of smart city in Makassar city is one of the efforts in realizing the vision and mission of Makassar City, "Makassar City a comfortable World for all". One of the missions of Makassar city are realizing Smart governance in the conduct of the Government. Some legislation has been set and became a reference in the implementation of the program Smart City in the city of Makassar, namely law number 11 Year 2008 of the information and electronic transactions, which describes one of his goals is to improve the effectiveness and efficiency of public services.

In addition, the implementation of smart city in the region is also a national policy framework is set out in the instructions of the President of the Republic of Indonesia number 3 of 2003 about policy and national strategy for the development government communication information and technology utilization in the process of government (e-government) will improve the efficiency, effectiveness, transparency and accountability of the organization of the government. 


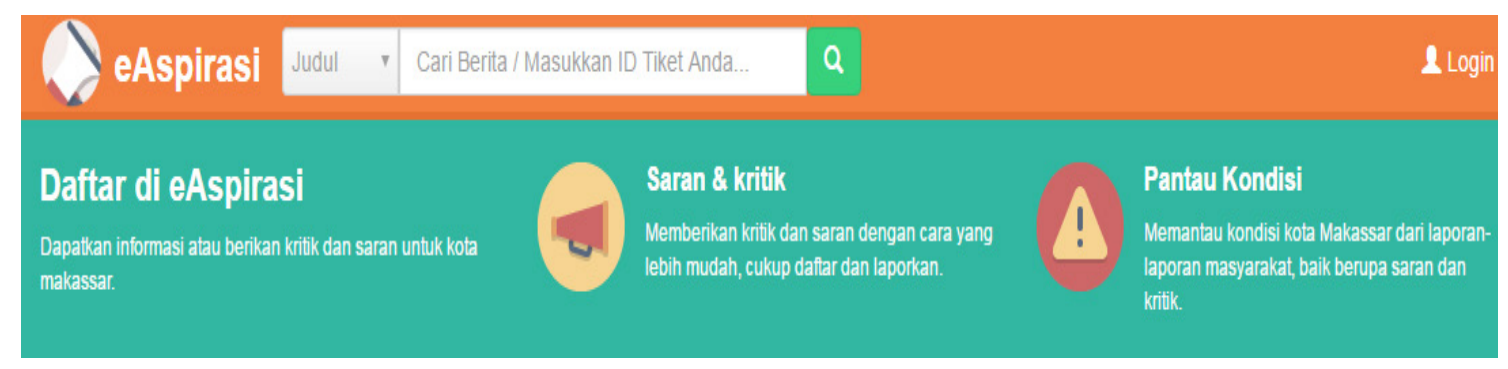

Figure 5

E-aspiration Service of Makassar City

Source: http://makassarkota.go.id/aspirasi/

Handling service complaints in Makassar city has $45 \%$ response rate of the survey from CRC (Celebes Research Centre) in 2016. This proves that the government should be able to provide more innovation in the service of the complaint service in Makassar city(viva.co.id).

E-aspiratin service in Makassar city is one of the media of smart governance.

This service is used for, the first, give criticism or suggestions with the easier way, by simply registering and creating an account and report on some of the events that occurred in the city of Makassar. Second, in addition to delivering e-service aspirations complaints also serve to monitor conditions in Makassar city via submission of inspiration held by their respective districts. Display of e-aspiration service can be seen in the figure 5.

\section{Implementation of E-aspiration Service}

1. The Source of the Complaints

In providing a complaint through e-aspiration is all the communities that have been registered through the ID-Report by filling form briefly included: email, name and password. One of the challenges in registering an account aspiration is not providing charging NIK.Advantage by incorporating NIK is one way to automatically data from people have recorded that directly can be integrated with the link service of population and the civil registry of the city of Makassar. How to register in e-aspiration of Makassar city which can be seen in figure 6 .

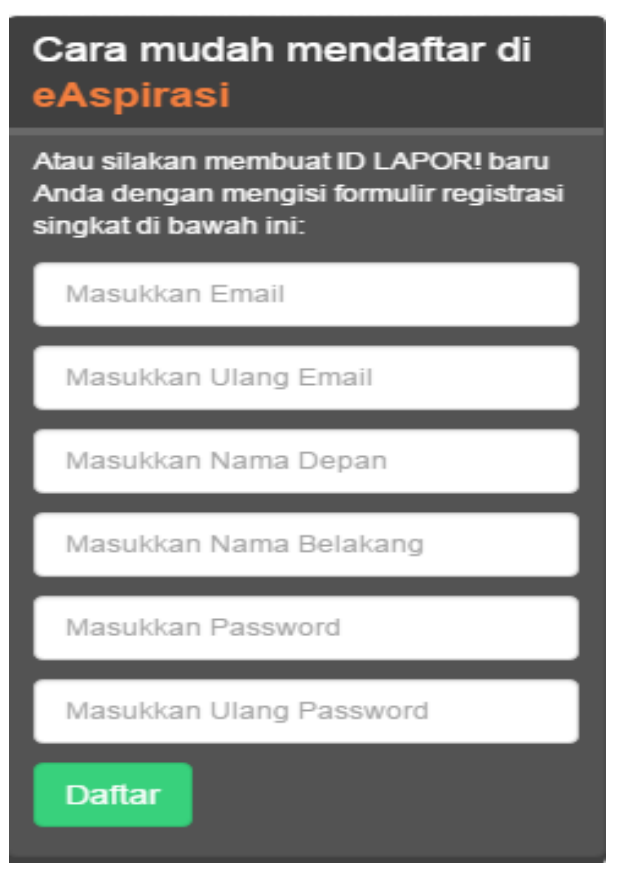

Figure 6

How to register in e-aspirations

Source:http://makassarkota.go.id/aspirasi/ 
2. Content of Complaints

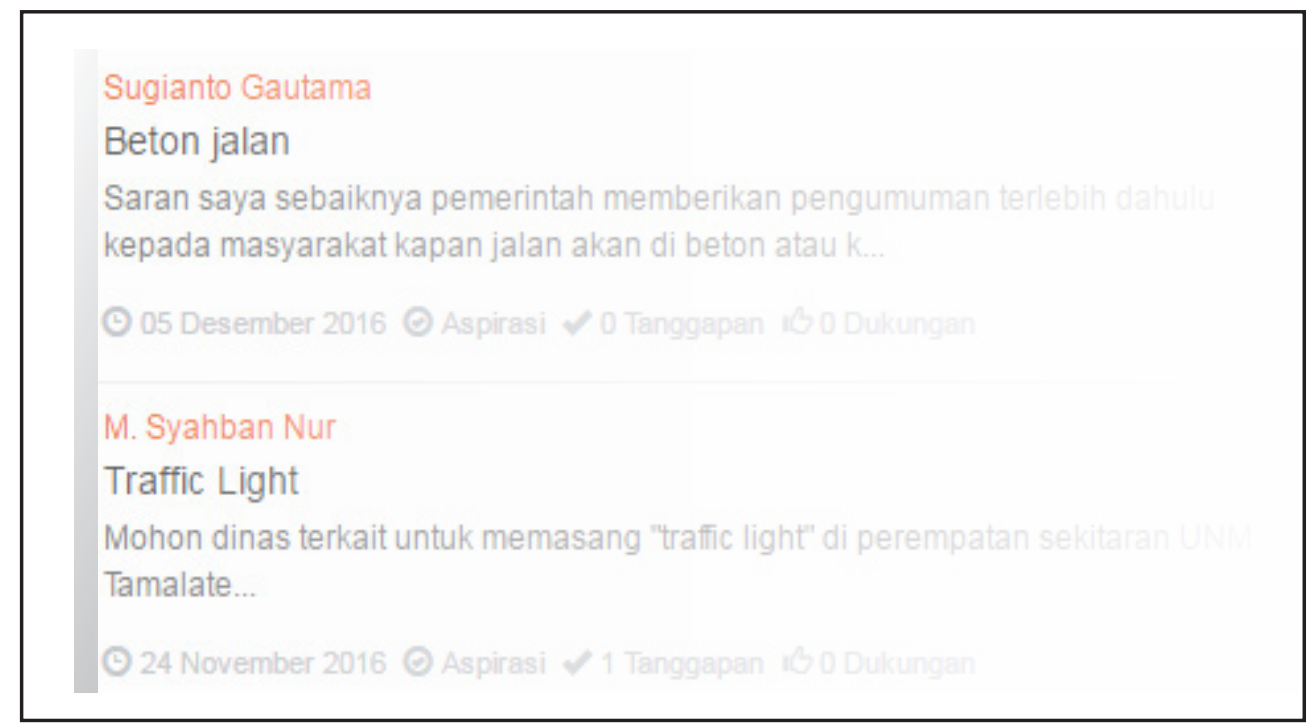

Figure 7

The example of Public Complaints in e-aspiration

Source:http://makassarkota.go.id/aspirasi/

The contents of the complaint in the e-aspiration is all suggestions and criticisms submitted by celebrated to entering the own title/category of complaint. In this e-complaints aspirations no specifically listed categories of its complaint. An example the public complaint submitted can be seen in figure 7 .

3. The Service Unit to Handling the Complaints.

The unit of public complaints service that are in Makassar city perfomed by sub section complaints by working with exiting surroundings of institution. Sub unit complaints in Makassar city has the duties and functions that is collecting data and material related public complaints, conduction coordination with relevant agencies as well as preparing the mechasim and procedure of public complaints. Every complaint that is intended in general to Government of Makassar city takes 3 hours to be processed as well as provide answers to complaints. While the complaints are purely technical and aimed at a specific Institution takes 3 days to do the confirmation to the institutions that provide answers to the complaints.

4. Response of Complaints

In carrying out the handling of the complaint submitted by the community is done with the following steps can we seen in figure 8.

5. Feedback

The community give freedom in presenting comments on the reply and confirmation provided by the 


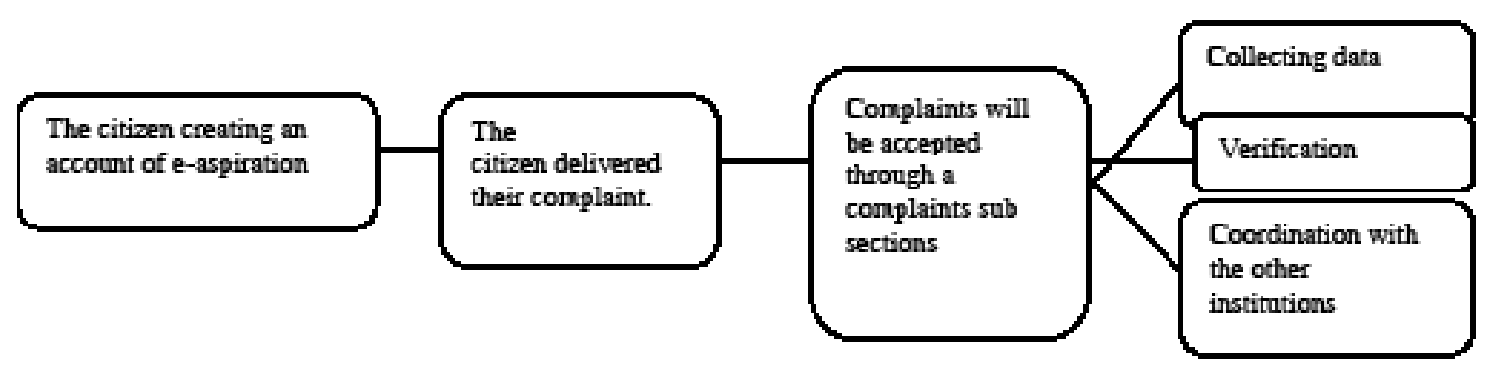

Figure 8

Step of Responds the Complaints

government. But on e-aspiration service responds given by community is still very slow, it is also coused by system service that are frequently misbehaving servers.

6. Report on the Handling of Complaints Makassar City Government still has not properly manage any complaints that come in. This is proved information on the number of report submission of complaints every year as well as the dominant aspect of the complaint were complained by the community. Therefore, the government should be able to execute its commitment to provide specific report as an effort to repair the condition in Makassar city.

\section{The Challenges of Implementing e-As- pirations}

In the implementation of e-complaints service aspirations still experienced some challenges that greatly affect the participation of the community, among other things:

1. Quality System

From the website e-aspiration Makassar City this quality of each system is not very supportive. For example, on this website access, each of data is often error occurred as well as the participation of the community is still very low. The complaint submitted by the public in 2016.

2. The quality of Information

Information services complaint still very less, the complaint that either should be able to inform the total statistics every year product/ total complaint that goes to the GovernmentofthecityofMakassar,plot resolution of complaints and nothing much in the success of the handling of the complaint.

3. Quality of service

Service on easpiration website often experience distruptions affecting aspects of community participation as well as the responsiveness of government. Complaint service should be able to provide fash service and facilitate community.

\section{CONCLUSION}

The e-government aspirations in Makassar city to provide excelent service to the public is still not optimal. 
Therefore, needed some improvement, among others, improve the accesable of information systems, the quality of information by displaying product every year success in handling public complaints, and improvement of quality service by improving the responsiveness of government.
The Government should also strive to Makassar city in enhancing public participation through on going activities to provide socialization to society to use of the e-aspirations service satisfy the aspects of pasrticipation and response/feedback from the community at every answer to complaint presented.

\section{BIBLIOGRAPHY}

Abu-Shanab, E. (2014). Antecedents of trust in e-government services: an empirical test in Jordan. Transforming Government: People, Process and Policy, 8(4), 480-499.

Colesca, S. E. (2015). Understanding trust in e-government. Engineering Economics, 63(4).

Cordella, A., \& Tempini, N. (2015). E-government and organizational change: Reappraising the role of ICT and bureaucracy in public service delivery. Government Information Quarterly, 32(3), 279-286.

Direktorat Aparatur Negara Kementerian Perencanaan Pembangunan Nasional. (2010). Laporan Kajian Manajemen Pengaduan Masyarakat dalam Pelayanan Publik.

Ecquria. (2016, October 17). Makassar Government and Ecquaria to Collaborate in Smart City Development. Retrieved May 27, 2017, from Ecquria: http:/www.ecquaria.com/ makassar-government-and-ecquaria-to-collaborate-in-smart-city-development/

European Parliamentary Research Service. (2015). e-Government Using technology to improve public services and democratic participation. EU: European Parliamentary Research Service.

Fajri Siregar, L. K. (2017, February 28). Technology and transformed governance in Indonesia. Retrieved May 28, 2017, from Making All Voices Count: http://www. makingallvoicescount.org/blog/technology-transformed-governance-indonesia/http:// www.makingallvoicescount.org/blog/technology-transformed-governance-indonesia/ http://www.makingallvoicescount.org/blog/technology-transformed-governanceindonesia/http://www.makingallvoicescount.org/blog/technology-transformedgovernance-indonesia/

Hajiali, Ismail. (2016). Sombore dan Smart City Kota Makassar diakses pada Website Dinas Komunikasi dan Informatika Kota Makassar.

Indonesia, I. P. (2003). Patent No. 3. Indonesia.

Instruksi Presiden Republik Indonesia Nomor 3 Tahun 2003 tentang Kebijakan dan Strategi Nasional Pengembangan e-government.

KOMINFO. (2015). Infrastruktur TIK, Layanan Informasi Dan Dinamika Sosial. Jakarta, DKI Jakarta, Indonesia: Litbang.

KOMINFO. (2012). Roadmap Pembangunan e-Government (Depkominfo).

Lu, N. L., \& Nguyen, V. T. (2016). Online Tax Filing-E-Government Service Adoption Case of Vietnam. Modern Economy, 7(12), 1498.

Maja Bott, G. Y. (2014). The Role of Crowdsourcing for Better Governance in International Development. Open 
Muhammad Nur Abdurrahman. 2016. Hasil survey kinerja Pemerintah Kota Makassar. Accessed from https://news.detik.com/berita/3375312/hasil-survei-kinerja-wali-kota-makassarpuaskan-warganya.

Norris, D. F., \& Reddick, C. G. (2013). Local e-government in the United States: Transformation or incremental change?Public Administration Review, 73(1), 165-175.

Prasetya, Dimas Ramdhana, at al. Analisis Pengelolaan Pengaduan Masyarakat dalam Rangka Pelayanan Publik (Studi pada Dinas Komunikasi dan Informatika Kota Malang). Jurnal Administrasi Publik (JAP,) Vol. 2, No. 1, Hal 1151-1158

Tim PSPPR UGM. (2016). Road MAP Kota Yogyakarta Menuju Smart City. WORKING PAPER PSPPR 2016.

Tisyo Haryono, Y. K. (2016, October 16). Current Status and Issues of E-Government in Indonesia. Retrieved May 28, 2017, from ASEAN: http://asean.org/?static_post=current-statusand-issues-of-e-government-in-indonesia

Weerakkody, V., Irani, Z., Lee, H., Hindi, N., \& Osman, I. (2016). Are UK Citizens Satisfied with E-Government Services? Identifying and Testing Antecedents of Satisfaction. Information Systems Management, 33(4), 331-343

William J. Kramer, B. J. (2007). The Role of the Information and Communications Technology Sector in Expanding Economic Opportunity. Cambridge, Massachusetts, USA: Harvard University. 